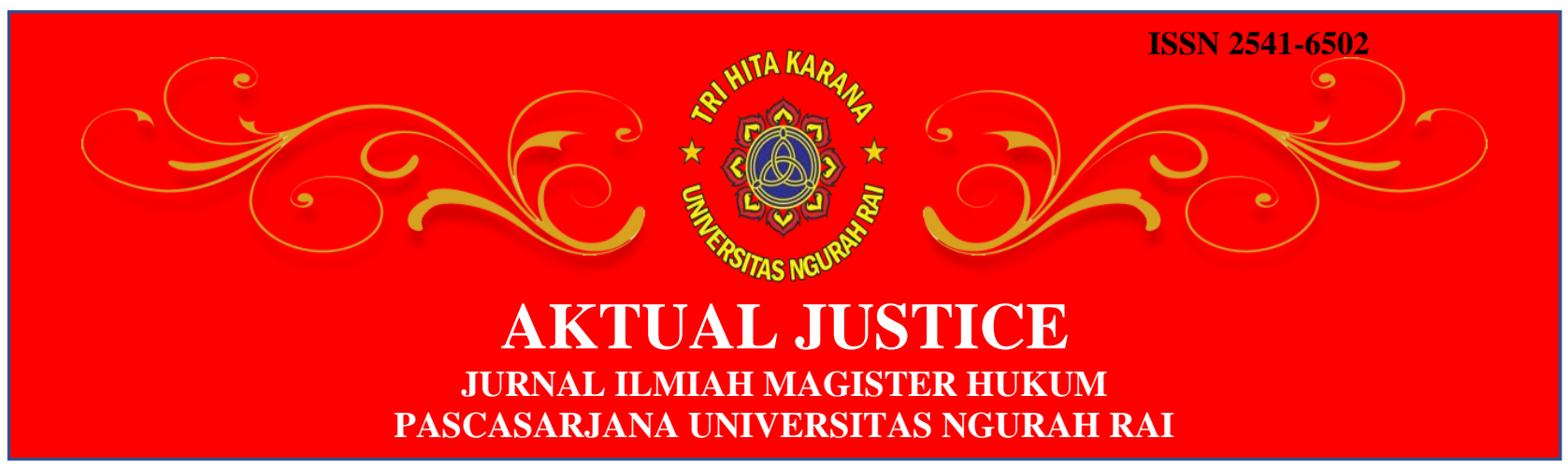

\title{
URGENSI PENETAPAN ATURAN \\ JASA MAKELAR DALAM TRANSAKSI JUAL BELI TANAH
}

\section{Cokorde Istri Dian Laksmi Dewi}

Dosen Magister Hukum Universitas Ngurah Rai Denpasar, Email: cokdild@gmail.com

\section{Abstract}

The relationship between the seller and buyer was between his servoci so that a transaction coul take place an intermediary in a land deal is called a broker. The realtor that supplied her service earned her fee, the arrangement of brokers appears in the statute of commerce and the minister of commerce's regulation of the company that regulates the magnitude of the broker fee minimal is a $2 \%$ and maksimal $5 \%$. But, the regulations can only apply to certified broker, as for the uncertified broker we refer to as the trandisional broker to run the broker function and set it on outside the prevailing rules.

For unswer the problem using a normative law research method by using a legals approach and othe regulation to answer about the urgency of a policy on the deployment to a broker. According to the tittle of this post is the urgency ot the brokerage rules in the land deal because if it is not established immediately, it will result in uncontrolled land price or demage to the seller the point of sale to be low after being deducated with the cost of notary, clas tax liability and broker fee.

Key word: Urgency, broker fee and buying land.

\section{Abstrak}

Hubungan antara penjual dan pembeli terdapat pelantara yang memberikan jasanya agar transaksi jual beli dapat terjadi, pelantara dalam transaksi jual beli tanah disebut makelar. Makelar dalam memberikan jasanya berhak mendapatkan fee, pengaturan tentang makelar terdapat dalam Kitab Undang - Undang Hukum Dagang dan Peraturan Menteri Perdagangan No.51/M-Dag/PER/7/2017 tentang Perusahaan Perantara Perdagangan Properti yang mengatur besarnya fee makelar adalah minimal $2 \%$ dan maksilam $5 \%$. Namun peraturan tersebut hanya dapat berlaku kepada makelar yang telah bersertifikat, sedangkan untuk makelar yang tidak bersertifikat yang kita sebut dengan makelar tradisional menjalankan fungsi makelar dengan menetapkan fee di luar ketentuan yang berlaku.

Untuk menjawab permasalahan tersebut mengunakan metode penelitian hukum yuridis normative, dengan menggunakan pendekatan undang - undang dan peraturan lainnya untuk menjawab tentang urgensi dalam penetapan sebuah aturan tentang pemberian jasa makelar, sesuai dengan judul tulisan ini adalah Urgensi Penetapan Aturan Jasa Makelar Dalam Transaksi Jual Beli Tanah. Karena apabila tidak segera ditetapkan maka akan mengakibatkan harga tanah 
yang tidak terkendali atau kerugian pada penjual karena pokok penjualan tanah menjadi rendah setelah dikurangi dengan kewajiban pajak, biaya notaris dan fee makelar.

Kata Kunci : Urgensi, Fee Makelar, Jual Beli Tanah

\section{Pendahuluan}

Tanah merupakan objek vital kebutuhan hunian masyarakat, selain sebagai pijakan hunian tanah juga menjadi investasi fasif yang memiliki nilai investasi tinggi dengan tingkat resiko kerugian yang sangat rendah. Peluang dunia jual beli tanah membentuk sebuah komunitas penyaluran jual -beli tanah dengan bertujuan untuk mendapatkan keuntungan, orang - orang yang mencari keuntungan dengan cara memfasilitasi antara penjual dan pembeli tanah sering kita kenal dengan makelar. Dalam kamus besar Bahasa Indonesia makelar adalah pedagang perantara yang menghubungkan pedangan yang satu dengan yang lain dalam jual beli atau antara penjual dan pembeli (saham dan sebagainya);cengkau; makelar; pialang. ${ }^{1}$

Pengertian lain diartikan sebagai orang atau badan hukum yang berjual beli sekuiritas atau barang untuk orang lain atas dasar komisi, ${ }^{2}$ atau pedagang perantara yang berfungsi menjualkan barang orang lain dengan mengambil upah tanpa menanggung resika, dengan kata lain makelar ialah penengah antara penjual dan pembeli untuk memudahkan jual beli.

Pengaturan tentang makelar diatur dalam Kitab Undang-Undang Hukum Dagang (KUHD) bagian kedua pasal 62-73, dimana dalam pasal 62 KUHD, makelar adalah seseorang pedagang perantara yang diangkat oleh gubernur jendral atau(presiden) atau oleh pembesar yang dinyatakan

${ }^{1}$ Kamus Besar Bahasa Indoensia.Broker. https://kbbi.web.id/broker. Diakses pada 12 Oktober 2020.

${ }^{2}$ Kamus Besar Bahasa Indoensia.Makelar. https://kbbi.web.id/broker. Diakses pada 12 Oktober 2020. 
berwenang untuk itu ia menyelenggarakan perusahaanya dengan melakukan pekerjaan yang diatur dalam pasal 64 KUHD, mendapatkan upah atau provisi, atas amanat dan nama orang orang dengan siapa ia tidak mempunyai sesuatu hubungan yang tetap. Dengan kata lain, makelar itu ialah penengah antara penjual dan pembeli untuk memudahkan terlaksananya jual beli tersebut.

Dalam dunia makelar atau jual beli tanah tidak ada aturan yang pasti dan mengikat mengenai kewajaran dalam pemberian jasa kepada makelar, sehingga terkesan hukum rimba berlaku dalam dunia makelar dimana para makelar mendominasi jual beli tanah dengan sistem yang mereka ciptakan sendiri dengan permainan pendanaan untuk menutup atau mengunci tanah-tanah strategis untuk kemudian dijual kembali dengan nilai yang lebih besar. Seperti misalnya makelar yang memiliki pembeli akan menutup akses antara penjual dan pembeli dalam bernegosiasi sehingga para makelar akan memegang monopoli dalam transaksi jual beli tersebut dan negosiasi harga hanya terjadi antara makelar dan penjual baru kemudian makelar menyampaikan kepada pembeli, disinilah akan timbul permainan harga dan pemberian jasa (fee makelar) kepada makelar dikarenakan antara penjual dan pembeli memiliki kepentingan yang besar dengan makelar, dalam dunia percaloan tanah saat ini dibali fee makelar berkisar antara 15\% sampai dengan 30\%. Sebenarnya pemerintah telah merevisi aturan tentang perusahaan perantara property yang tertuang dalam Peraturan Menteri Perdagangan No.51/M-Dag/PER/7/2017 tentang Perusahaan Perantara Perdagangan Properti. Dalam aturan baru tersebut pemerintah membatasi komisi bagi makelar yang melaksanakan jual beli yakni minimal 2\% dan maksimal 5\% dari nilai transaksi dan disesuaikan dengan lingkup jasa yang diberikan kepada pengguna jasa. Pengamat propeti Ali Tranghada bilang, revisi aturan ini memberi penegasan saja soal batas nilai komisi bagi makelar. 
Tujuannya, "supaya makelar tidak semena - mena dalam menerapkan tarif maksimal komisi,"3 Tetapi dalam kenyataanya hal tersebut sulit untuk dilakukan, sehingga dalam penulisan ini diharapkan dapat memberikan solusi karena dengan tingginya fee makelar akan membuat harga jual tanah menjadi tinggi yang berbarengan dengan kewajiban pajak yang harus dibayar baik oleh penjual maupun pembeli. Yang menjadi urgensi dari permasalahan tersebut adalah penetapan aturan tentang jasa makelar yang bersifat mengikat sehingga para makelar wajib tunduk pada aturan tersebut. Untuk itu dalam penulisan ini mengangkat judul Urgensi Penetapan Peraturan Jasa Makelar Dalam Transaksi Jual Beli Tanah.

\section{Metode Penelitian}

Jenis penelitian hukum yang dilakukan adalah penelitian hukum normative (normatof legal research $)^{4}$ dengan mengidentifikasi, mendeskripsikan serta menganalisis tentang pentingnya sebuah aturan tentang pemberian jasa makelar, dimana peraturan tersebut bersifat mengikat dan para makelar wajib tunduk pada aturan tersebut guna menjaga stabilitas harga tanah. Penelitian ini dilakukan dengan mengkaji, memaparkan dan menganalisis norma hukum yang ada pada bahanbahan hukum dengan menggunakan pendekatan perundang-undangan yang berkaitan dengan permasalahan yang diangkat.

\section{Hasil dan Pembahasan}

${ }^{3}$ Agus Triyono, Dulpa Kartini.2017. Kemdag Batasi Maksimal Komisi Broker 5\%. https://nasional.kontan.co.id/news/kemdag-batasi-maksimal-komisi-broker-properti$\underline{5}$, diakses pada jumat, 15 Oktober 2020 .

4Jhon Ibrahim. (2006). Teori dan Metodelogi Penelitian Hukum Normatif. Malang; Bayumedia.h.57. 
Dalam praktik transaksi perdagangan atau bisnis dewasa ini, Lembaga keperantaraan dalam bidang peniagaan menunjukkan pran yang meningkat. Bahkan terkadang transaksi bisnis tersebut harus melalui perantara. ${ }^{5}$ Perantara yang dimaksud dalam hubungan bisnis adalah termasuk makelar. Salah satu bisnis yang menekankan pada aspek kepercayaan adalah makelar, Makelar adalah seorang perantara yang menghubungkan pengusaha dengan pihak kedua untuk mengadakan berbagai perjanjian. ${ }^{6}$ termasuk juga makelar tanah atau properti, sejak awal tahun 2000 an bahkan sebelumnya telah banyak berkembang perusahann yang bergerak dibidang jasa penyalur jual beli ini, perkembangan makelar berkembang pesat khususnya di negara - negara berkembang, yang perekonominannya sedang tumbuh dengan tingkat konsumsi dan investasi yang tinggi terutama di Benua Eropa, Amerika Serikat, Australia dana beberapa negara asia timur termasuk indonesia. Di Indonesia bisnis ini amat berkembang dalam 10 tahun terkahir.

\section{a. Makelar Dalam Transaksi Jual Beli Tanah}

Ada makelar yang membentuk perusahaan berbadan hukum, ada yang memilih berjalasan seorang diri sebagai agen properti independen yang profesional dan ada pula yang membentuk suatu kelompok makelar terdiri dua orang atau lebih.7 Tugas pokok makelar menurut KUHD : ${ }^{8}$

a. Memberi perantara dalam jual beli.

b. Menyelenggarakan lelang terbuka dan lelang tertutup.

c. Menaksir untuk bank hipotik dan maskapai asuransi.

5 Davy Ibu Aziz,dkk. (2016) .Tinjauan Yuridis Pernjanjian Jual Beli Melalui Jasa Perantara.Program Studi S1 Ilmu Hukum, Fakultas Hukum, Universitas Diponogoro.h.2

${ }^{6}$ Ressa Felinda. (2020) .Praktik Makelar Ditinjau Dari Hukum Ekonomi Syariah (studi kasus di konvensi Amin Kelurahan Ganjar Agung Kota Metro).Tesis.Hukum Ekonomi Syariah.Institut Agama Islam Negeri (IAIN) Metro.h.5.

7BambangWarsita.http:/ / bambang-warsita.blogspot.co.id/2013/06/15-tipsjitu-bisnis-menjadi-agen-atau.html diakses pada hari selasa, 19 Oktober 2020.

8 http://repo.iain-tulungagung.ac.id/13966/5/BAB\%20II.pdf. Diaksek pada hari jumat, 15 Oktober 2020. 
d. Mengadakan monster barang - barang yang akan diperjual belikan.

e. Menyortir party - party barang yang akan diperjual belikan.

f. Memberikan keahliannya dalam hal kerusakan dan kerugian.

Selain tugas pokok tersebut sebagaimana diatur dalam KUHD, seorang makelar juga memiliki kewajiban dan larangan sebagaimana yang diatur dalam KUHD, sebagai berikut :

- Pasal 66 KUHD, seorang makelar diwajibkan untuk memiliki buku saku dan buku harian untuk mencatat setiap transaksi atau perjanjian yang telah dibuatnya ke dalam buku harian tersebut dengan teliti.

- Pasal 65 ayat (2), larangan bagi seorang makelar adalah berdagang dalam lapangan perusahaan yang sama di mana ia diangkat sebagai makelar. Larangan lainnya, seorang makelar tidak boleh menjadikan dirinya penjamin (borgtoch) dalam perjanjian yang ia perantarai.

Jadi dalam KUHD di Indonesia jelas diatur bahwa bisnis makelar adalah bisnis yang telah diterakan dan disahkan di Indonesia dalam mengatur mengenai pengangkatan makelar, kewajiban makelar. ${ }^{9}$ Apabila makelar melakukan pelanggaran, konsekuensi atas pelanggaran yang dilakukanya maka akan dipailitkan (dinyatakan pailit oleh pengadilan) dan pemecatan"makelar.

Makelar seperti yang telah diterjemakan dalam KUHD, ruang lingkup kegiatan seorang makelar diatur dalam Keputusan Menteri Perdagangan No. 33/M-DAG/PER/8/2008 Tentang Perusahaan Perantara Perdagangan Properti dalam pasal 2 , dimana kegiatan makelar meliputi : jasa jual beli, jasa sewa menyewa, jasa penelitian dan pengkajian

9 Melyana Aprilia. (2016). Eksistensi Makelar (Tanah) Ditinjau Dari Perspektif Hukum Islam (Studi Kasus di Desa Onewila Kec. Ranomeeto Kab. Konawe Selatan).Kendari.Institur Agama Islam Negeri (IAIN) Kendari. h. 22. 
property, jasa pemasaran, jasa konsultasi dan penyebaran informasi. Dalam pasal 14 disebutkan tentang kewajiban dari seseorang yang makelar adalah :

1) Setiap perusahaan wajik memiliki SIU-P4;

2) Kewajiban untuk memiliki SIU-P4 sebagaimana di maksud pada ayat 1) dikecualikan bagi kantor cabang perusahaan;

3) SIU-P4 sebagaimana dimaksud pada ayat 1) hanya berlaku untuk melakukan kegiatan usaha perdagangan property sebagaimana dimaksud dalam Pasal 2.

4) SIU-P4 berlaku selama perusahaan menjalankan kegiatan usahanya di seluruh wilayah Negara Republik Indonesia.

5) Perusahaan sebagaimana dimaksud pada ayat 10 wajib melakukan pendaftaran ulang setiap 5 (tahun) di tempat penerbitan SIU-P4.

Ditelaah dari aturan Menteri perdagangan tersebut yang diatur mengenai makelar disini adalah makelar dalam bentuk badan usaha resmi yang memiliki ijin usaha, tetapi dalam aktivitas dunia makelar yang menjadi makelar atau yang mengatasnamakan dirinya atau kelompoknya sebagai makelar adalah orang perorangan atau kelompok perorangan yang menjalankan ativitasnya secara mandiri sehingga tidak tunduk oleh aturan undang-undang tersebut diatas.

Dengan adanya makelar yang paham dan menangani setiap transaksi dengan baik dan benar maka akan sangat memudahkan bagi pihak penjual dan pembeli dalam bertransaksi. Itulah yang sebenarnya menjadi tujuan dari adanya profesi makelar ini agar dapat memberikan bantuan dalam transaksi jual beli tanah atau property agar transaksi dapat berjalan dengan aman dimana keabsahan legalitas terjamin, meminimalisasi kerugian dan lebih efektif karen proses transaksi menjadi lebih cepat. Bagi makelar (perantara), atau biro jasa mendapat laprangan 
pekrjaan dan uang jasa dari hasil kerjanya itu. ${ }^{10}$ Untuk mengetahui lebih dalam mengenai makelar property maka kita harus memahami terlebih dahulu ruang lingkup pekerjaanya. Secara umum pekerjaan makelar property adalah Menyusun program pemasaran property yang sistematis diantarannya sebagai berikut :

Membuat Database Listing :

1. Membuat iklan baik melalui brosur, papan promosi, iklan media cetak, radio/tv maupun media internet.

2. mengantar calon pembeli ke lokasi yang diinginkannya.

3. Membantu proses negosisasi.

4. Melakukan kegiatan Open House.

5. Memberi laporan lisan maupun tulisan keada klien mengenai perkembangan negosiasi.

6. Bekerja sama dengan pihak notaris yang terpercaya dan berpengalaman.

7. Mengumpulkan, mengecek persyaratan dan kelengkapan data penjual ataupun pembeli yang dibatu oleh Notaris dan instansi yang berwenang. Data dari pihak penjual dan pembeli berupa KTP, akta nikah, akta kelahiran anak (jika diperlukan) dan kartu keluarga.

8. Mengecek keabsahan dan kelengkapan dokumen property berupa sertifikat bangunan dan tanah yang asli, IMB, ajb sebelumnya, bukti lunas PBB dan bukti luas biaya lainnya.

9. Mengingatkan pihak penjual akab biaya yang harus ditanggungnya berupa PPH, Pelunasan PBB sampai dengan tahun terakhir dan pembayaran komisi 2\%; 2,5\%; atau 3\% dari nilai transaksi kepada makelar property yang bersangkutan.

10 Sopyan. (2017). Analisi Praktek Samsa.rah (makelar) Dalam Jual Beli Sepeda Motor di Kabupaten Bone. None.Istitut Agama Islam Negeri (IAIN). h. 11 
10. Mengingatkan pihak pembeli biaya yang harus ditanggung yakni BPHTB (pajak pembeli) biaya notaris (biaya akta jual beli dan balik nama)

11. Membantu lancarnya transaksi jual beli propperti. ${ }^{11}$

Uraian dari pengertian makelar dilihat dari KUHD dan peraturan Menteri perdagangan tersebut berfokus pada makelar resmi yang bernaung pada sebuah badan hukum, sedangkan makelar yang tidak berada pada sebuah bendera badan hukum perlu untuk mendapatkan perhatian dan pengaturan yang jelas, sehingga dapat penulis simpulkan makelar dapat kita katagorikan menjadi 2 yaitu :

1. Makelar bersertifikat.

Makelar bersertifikat akan bekerja dibawah naungan perusahaan real estate tertentu, sehingga pembayaran komisi akan mengikuti prosedur perusahaan. ${ }^{12}$

2. Makelar tradisional.

Makelar tradisional adalah makelar yang tidak bekerja dibawah naungan perusahaan, serta tanpa dilengkapi sertifikat keahlian sebagai seorang makelar.

Makelar tradisional yang seperti inilah yang menjadi pokok permasalahan dalam penulisan ini, bagimana kelompok perorangan makelar ini di dalam menjalankan kegiatanya dapat tunduk dengan undang-undang sehingga tidak menimbulkan kerugian bagi pihak penjual dan pembeli termasuk dapat menjaga stabilitas harga tanah.

Dalam penulisan ini akan difokuskan dengan fee/jasa makelar tradisional yang berdampak pada harga jual beli tanah sehingga perlu

${ }^{11}$ Wahyu Edi, Rumah Idaman, http:// wedhart.blogspot.co.id/rumah-idaman , diakses pada hari selasa 19 Oktober 2020.

12 Ahmad Sopian. (2020). Jadi Makelar jual Beli Tanah ? ini Besaran Fee Anda. https://jendela360.com/info/komisi-jual-beli-tanah. Diakses pada 12 Oktober 2020. 
dibuat sebuah aturan untuk mengatur pemberian fee untuk makelar tradisional.

\section{b. Urgensi Penetapan Aturan Jasa Makelar Dalam Transaksi Jual Beli Tanah}

Dalam praktik umum penggunaan jasa didasari pada kepercayaan yang diberikan oleh pengguna jasa terhadap pemberi jasa, demi mendapatkan kepastian dalam kepercayaan tersebut, umumnya para pihak akan mengikatkan diri dalam sebuah perjanjian tertulis yang sedikitnya harus memuat :
a. Lingkup kegiatan atau jasa yang akan diberikan;
b. Objek yang diperjanjikan;
c. Hak dan kewajiban para pihak;
d. Nilai atau persentasi dan tata cara pembayaran komisi / fee;
e. Masa berlaku perjanjian meliputi masa aktif dan masa pasif;
f. Penyelesaian perselisihan.

Begitupula dengan seorang makelar yang memberikan jasanya untuk membantu proses jual beli baik berupa tanah ataupun property lainnya, dimana makelar berhak menerima imbalan jasa/ fee dari pemberian tugas atas jasa yang deiberikan. Seorang makelar/ makelar berhak untuk menerima pembayaran jasanya apabila objek yang disalurkan untuk diperjual belikan tersebut telah laku terjual dan penjual mendapatkan pembayaran dari pembeli, atau berdasarkan kesepakatan diantara para pihak. Namun, tidak semua transaksi yang dilakukan dengan makelar dibuatkan sebuah perjanjian secara tertulis tetapi lebih pada perjanjian lisan atas dasar kepercayaan. Yang sering terjadi adalah pemilik tanah yang terdesak untuk segera menjual tanahnya menjadi tergantung kepada makelar, sehingga tanpa perhitungan yang matang menyepakati pemberian jasa makelar yang melebihi dari aturan yang dibenarkan oleh undang - undang, sebagaimana yang telah diatur dalam 
Peraturan Menteri Perdagangan No.51/M-Dag/PER/7/2017 tentang Perusahaan Perantara Perdagangan Properti yang menetapkan besarnya fee makelar adalah minimal 2\% dan maksimal 5\%. Sudah sangat umum terjadi dimasyarakat untuk transaksi diatas Rp. 1.000.000.000,- ( satu miliar rupiah) maka fee yang harus diberikan adalah 5\% sampai dengan $10 \%$, sedangkan untuk transaksi dibawah Rp. 1.000.000.000,- (satu miliar rupiah) maka fee makelar yang harus dibayarkan adalah 10\% sampai dengan 15\%, dalam nominal persentasi akan terkesen cukup ringan tetapi setelah dilakukan perhitungan dari nilai harga jual dikurangi pajak-pajak, biaya notaris dan fee makelar maka penjual akan kehilangan 20\% sampai dengan 30\% dari harga jual tanahnya. Setelah hal tersebut terjadi barulah akan timbul permasalahan, dimana penjual akan merasa rugi karena potongan penjualan yang besar. Perselisihan antara makelar dan penjual tidak jarang sampai disidangkan di meja hijau, terlebih lagi apabila sebelumnya tidak ada kesepakatan tertulis antara penjual dan makelar mengenai jasa penjualan tersebut.

Pemilik tanah yang telah mempercayakan penjualan tanahnya kepada makelar dengan perjanjian komisi/fee tidak perlu lagi memikirkan cara pemasaran dari tanahnya, sehingga pemilik tanah cukup menunggu pembeli yang akan datang kepadanya melalui para makelar. Umumnya para makelar akan memberikan jasanya mulai dari negosiasi kepada pembeli, melakukan publikasi sampai pada pengurusan dokumen-dokumen yang diperlukan sampai dengan transaksi jual beli terjadi antara penjual dan pembeli di Notaris. Dalam satu sisi penjual akan dimudahkan karena memiliki aasisten pribadi yang mentransaksikan tanahnya yaitu makelar, tetapi dengan penguasaan seperti itu memiliki resiko yang cukup besar karena terlebih lagi makelar yang dipergunakan tidak memiliki ijin dan tidak ada jaminan hukum. 
Melihat sempitnya jangkauan tentang makelar dilihat dari ketentuan KUHD dan Peraturan Menteri Perdagangan dalam memberi batasan dalam penetapan fee makelar tradisional maka penulis beranggapan sangat perlu dibuatkan aturan khusus mengenai fee makelar tradisional yang dapat dipersamakan dengan makelar bersertifikat dan yang lebih terpenting adalah bagaimana sosialisasi yang dapat dilakukan oleh pemerintah untuk mencegah tingginya fee jual beli tanah yang berlaku di masyarakat. Seperti yang telah diuraikan diatas, dengan fee tanah yang besar di satu sisi akan membuat penjual menaikan harga jual tanahnya untuk mengurangin kerugiannya, disisi lain apabila penjual tidak menaikan harga tanahnya maka penjual akan mengalami kerugian yang cukup besar dikurangi dengan biaya - biaya yang harus dikeluarkan dalam transaksi jual beli tanah.

\section{Kesimpulan}

Makelar sebagai bentuk usaha jasa jual beli tanah dapat dikatagorikan menjadi dua yaitu makelar bersertifikat dan makelar tradisional, makelar bersertifikat akan tunduk pada ketentuan KUHD dan peraturan kementerian perdagangan dari pemberian fee atau jasanya, sedangkan makelar tradisional tidak dapat disentuh oleh KUHD dan Peraturan Menteri Perdagangan sehingga dapat menetapkan fee penjualan diluar apa yang telah diatur dalam Peraturan Menteri Perdagangan, penetapan fee yang diluar aturan tersebut membuat harga pasar dalam jual - beli tanah menjadi tidak terkendali, sehingga memunculkan paling tidak dua permasalahan yaitu :

1) Harga jual tanah menjadi tidak terkendali, dimana penjual akan menaikkan harga tanahnya, untuk mengurangi kerugian akibat besarnya potongan yang harus dibayarkan yaitu dari biaya-biaya pajak, biaya notaris dan fee makelar. 
2) Penjual berada dalam pihak yang dirugikan karena ketergantungannya dengan makelar, dimana hasil penjualan tanah menjadi rendah tetapi pajak - pajak yang harus dibayarkan termasuk biaya notaris dihitung berdasarkan transaksi real jual beli, bukan harga jual beli setelah dikurangi fee makelar.

Sehingga menjadi suatu yang mendesak akan adanya sebuah peraturan atau ketentuan yang memberikan batasan fee makelar khususnya bagi makelar tradisional untuk mengendalikan harga pasar.

\section{Daftar Pustaka}

\section{Buku}

Ibrahim Jhon. (2006). Teori dan Metodelogi Penelitian Hukum Normatif. Malang; Bayumedia.

Rosa Agustina, Hans Nieuwenhuis, dkk. (2012). Hukum Perikatan. Denpasar; Pustaka Larasan.

\section{Jurnal}

Aprilia Melyana. (2016). Eksistensi Makelar (Tanah) Ditinjau Dari Perspektif Hukum Islam (Studi Kasus di Desa Onewila Kec. Ranomeeto Kab. Konawe Selatan). Kendari.Institur Agama Islam Negeri (IAIN) Kendari.

Davy Ibu Aziz,dkk. (2016). Tinjauan Yuridis Pernjanjian Jual Beli Melalui Jasa Perantara.Program Studi S1 Ilmu Hukum, Fakultas Hukum, Universitas Diponogoro.

Felinda Ressa. (2020). Praktik Makelar Ditinjau Dari Hukum Ekonomi Syariah (studi kasus di konvensi Amin Kelurahan Ganjar Agung Kota Metro).Tesis.Hukum Ekonomi Syariah.Institut Agama Islam Negeri (IAIN) Metro

Sopyan. (2017). Analisi Praktek Samsa.rah (makelar) Dalam Jual Beli Sepeda Motor di Kabupaten Bone.None.Istitut Agama Islam Negeri (IAIN).

\section{Artikel Internet}


Agus Triyono, Dulpa Kartini. (2017). Kemdag Batasi Maksimal Komisi Broker 5\%. https://nasional.kontan.co.id/news/kemdag-batasimaksimal-komisi-broker-properti-5, diakses pada jumat, 15 Oktober 2020.

Ahmad Sopian. (2020). Jadi Makelar jual Beli Tanah ? ini Besaran Fee Anda. https://jendela360.com/info/komisi-jual-beli-tanah. Diakses pada 12 Oktober 2020.

Bambang Warsita. http://bambang-warsita.blogspot.co.id/2013/06/15tips-jitu-bisnis-menjadi-agen-atau.html . diakses pada hari selasa, 19 Oktober 2020.

Kamus Besar Bahasa Indoensia.Broker. https://kbbi.web.id/broker.

Wahyu Edi, Rumah Idaman, http://wedhart.blogspot.co.id/rumahidaman, diakses pada hari selasa 19 Oktober 2020.

http:// repo.iain-tulungagung.ac.id/13966/5/BAB\%20II.pdf. Diaksek pada hari jumat, 15 Oktober 2020. 